\title{
MEANING-MAKING OF A GROUP OF SOUTH AFRICANS IN THEIR EXPERIENCE OF LIV- ING WITH HIV: A PHENOMENOLOGICAL STUDY
}

\section{HG Pretorius}

D Litt et Phil (Psychology)

Professor

Deputy Chairperson, Department of Psychology, University of Johannesburg

Corresponding author: hgpr@lw.rau.ac.za

\section{N Goldstein}

D Litt. et. Phil (Psychology)

Student, Department of Psychology, University of Johannesburg

\author{
AD Stuart \\ D Litt et Phil \\ Professor \\ Chairperson, Department of Psychology, University of Johannesburg
}

Keywords: HIV/AIDS; meaning-making and HIV/AIDS in South Africa; disease-specific studies; biological, psychological and psychosocial experience of living with HIV/AIDS

\begin{abstract}
With the primary focus of disease specific studies on the medical and biological transmission and progression of HIVIAIDS, the lived experience and meaning-making of individuals who live with this disease, is a literary scarcity. Similarly, the idiosyncratic meaning-making of middle class citizens diagnosed with HIVIAIDS appears largely unexplored. Addressing these concerns, the aim of this article is to explore the lived experience and meaningmaking of four middle-class South Africans diagnosed with HIV. Open-ended questions were formulated and used to elicit the rich idiosyncratic meaning of the complex experiences of the participants. The research indicates that HIV/AIDS is experienced as an intrusive violation of one's way of being-in-the-world in relation to one's self and others and involves a complex process consisting of overwhelming and intense feelings. The research also indicates that, in the experience of living with HIVIAIDS, a space is created for the rediscovery of spirituality, religion and compassion. Consequently, an appreciation for life, a need for belongingness, community, and also a transcendence of the mundane by positive embrace of one's time on earth is facilitated in the experience of living with this disease. This positive shift in what it means to live with HIVIAIDS in South Africa might have important implications for the helping professions and from which many therapeutic benefits might derive.
\end{abstract}

\section{OPSOMMING}

Met die primêre fokus van siektespesifieke studies op die mediese en ook biologiese oordrag en progressie van MIVIVIGS, is daar 'n literêre skaarste oor die geleefde ondervinding en betekenisgewing van individue wat met hierdie siekte leef. Insgelyks, die idiosinkratiese betekenisgewing van middelklas individue wat met MIVIVIGS gediagnoseer is blyk asof dit nog nie ondersoek is nie. In 'n poging om hierdie leemte aan te spreek, verken die studie die geleefde ervaring en betekenisgewing van vier middelklas Suid-Afrikaners wat met MIV+ gediagnoseer is. Oopeinde vrae is geformuleer en gebruik om die ryk idiosinkratiese betekenisgewing van die komplekse ervarings van die deelnemers aan die lig te bring. Die navorsing dui aan dat MIVIVIGS ' $n$ indringende skending van persone se in-die-wêreld-wees in verhouding met hulleself en ander ervaar word, en dat dit 'n komplekse proses van oorweldigende en intense emosie behels. Die navorsing dui verder daarop dat, in die ervaring van leef met MIV/ VIGS, daar 'n ruimte geskep word vir die herontdekking van spiritualiteit, religie en medelye. Op hierdie wyse word 
'n waardering vir die lewe, 'n behoefte aan 'n gevoel van behoort-aan, en ook 'n uitstyging bo die alledaagse deur die positiewe aanvaarding van 'n persoon se tyd op hierdie aarde gefasiliteer deur die ervaring van leef

\section{INTRODUCTION}

As a worldwide pandemic, statistics reveal that HIV/ AIDS is fast becoming a major health crisis and psychological emergency in South Africa. Challenging and perplexing, HIV/AIDS is a disease confounded by the fact that it follows no precedent for coping psychologically or psychosocially. Given this however, few studies investigate the idiosyncratic lived experience of individuals diagnosed with this disease (Snyman, 1999:12). Furthermore, the experience of living with HIV/AIDS for middle class individuals is largely unexplored. The literature has identified these areas of sparse investigation to be significant gaps in the experience of living with HIV in South Africa.

Seeking to address these gaps, this study explores the lived experience and meaning-making of four middleclass South Africans diagnosed with HIV. The following working definition of HIV was utilised in this study so as to distinguish this from AIDS: (a) Infection of the Human Immunodeficiency Virus (HIV) refers to a person who has contracted the virus, and who tests positive for antibodies to HIV. At this stage, the individual has not yet contracted any of the opportunistic infections associated with AIDS (Lyell, 1995:56).

\section{BACKGROUND}

HIV/AIDS is an epidemic of grave proportions in South Africa. While sub-Saharan Africa is the most severely affected globally, the Southern African Development Community (SADC) is home to at least half of the estimated 24 million people with HIV/AIDS in this region (UNAIDS, in Shisana \& Simbayi, 2002:1). While much remains ambiguous and equivocal regarding the condition, it is unequivocally complex in its creation of untold anguish and tremendous social tragedy. Dauntingly, South Africa has the largest percentage of people living with HIV/AIDS in the world (UNAIDS, 2000:2).

The Department of Health estimated that over 5.3 million South Africans were HIV positive by the end of 2002 (Fredriksson \& Berry, 2003:2) and with a prevalence rate of $26.5 \%$. Although the prevalence rate in the South African population of $11.4 \%$ recorded in the Nelson Mandela/HSRC study (Shisana \& Simbayi, 2002:45) for the same year is markedly lower, the figures remain exceptionally high. Clearly tremendous challenges lay ahead in the fields of education, prevention and care (Fredriksson \& Berry, 2003:3).

Previously, the political response in South Africa to the HIV/AIDS epidemic has been "one characterised by denial, ministerial wrangling, the misallocation of resources and a muting of the seriousness of the virus by those forces either resisting or pushing for political transformation" (Webb, 1997:71). Consequently, HIV/ AIDS in South Africa exposed and intensified social prejudices, stereotypes, economic inequalities, discrimination and political injustices (Grundlingh, 2001:8).

Although a positive shift in the political milieu is now taking place and as is evidenced by the two abovementioned studies, it is perhaps the result of past taboos and discriminatory practices that the lived experience of many South Africans diagnosed with HIV/AIDS has been one of neglect.

\section{THE PSYCHOLOGICAL AND PSYCHOSO- CIAL CONTEXT OF HIV/AIDS}

According to Schlebusch and Cassidy (1995:1313), an important aspect of early research on HIV/AIDS concerns the division between physiological treatment interventions for the illness when compared to addressing the psychogenic makeup of the person. Accordingly, early research on HIV/AIDS as a biomedical condition was essentially focused on establishing a virus theory. By 1984 a shift in focus was observed to include multiple dimensions of the disease that incorporated a psychosocial approach.

In keeping with this new shift the World Health Organisation (in Sheikh \& Sheikh, 1989:29) defines health as a "state of complete physical, mental and social well-being, and not merely the absence of disease or infirmity." Drawing on the work of Maturana 
(1975:318), it is suggested that the manner in which an individual reacts, and in turn behaves, is based on the individual's internal structure, cognitions, personally constructed ideas, beliefs and attributions of meaning about the prevailing life-threatening situation. Similarly, the experience of living life with HIV/AIDS seems closely bound up, mediated and intercepted by an admixture of factors such as personality, spirituality, social support and quality of life. In unison, this admixture works to influence and shape the idiosyncratic lived experience of the illness (Levy, 1997:55; Ragsdale \& Morrow, 1990:357).

\section{HIV/AIDS IN SOUTH AFRICA AND HOLISM}

With over five million people in South Africa estimated to be HIV/AIDS infected, this disease is undoubtedly the most critical health and developmental crisis facing the country currently (Fredriksson \& Berry, 2003:2).

On a deeply personal level, the receiving of an HIV/ AIDS positive diagnosis precedes profound emotional distress for the individual, family and friends. In the absence of cure, meaningfulness of activities of human relationships and of life itself appears to be questioned (Presti, 1990:23). In turn, many people with HIV/AIDS begin to question whether meaning exists in their suffering (Louw, 1997:130).

In the event of illness, meaning-making of one's purpose in life becomes imperative to one's continued wellbeing. Proposing a three-dimensional view of the mind, body and spirit, Eastern philosopher, Takashima (in Gould, 1993) posits the spiritual self as integral in one's positive embrace of self in times of ill health. Similarly, the traditional African world-view of the individual incorporates a holistic perspective within which everything in the life of the world of the individual is included and deemed meaningful.

In contrast, Louw (1994:23) notes that the Western model of health denotes an analytical and diagnostic approach to physical well-being. A lack of South African studies investigating holistically, the idiosyncratic meaning of what it means to live with HIV/AIDS adds support to Louw's observation. Similarly, although the literature does reveal the importance of factors, such as spirituality, in the progression of HIV/AIDS (Ragsdale \& Morrow, 1990:356; Temoshok, 1988:193), studies of this nature are sparse. A positive shift that might serve to prompt future research in this field is the Nelson Mandela/HSRC study undertaken in 2002.

Joining hands with the Human Sciences Research Council (HSRC), the Nelson Mandela Foundation and Nelson Mandela Children's Fund identified a need for a national HIV/AIDS survey. Motivating the survey was the firm belief that, in order to manage the disease, current and accurate information that covered both cultural and demographic spectrums was required. From this, a national community-based study on the behavioural and socio-cultural determinants contributing to HIV/AIDS was launched. This pioneering study is the first systematically sampled, nationwide community-based survey of the prevalence of HIV in South Africa and as such, assumes great importance (Shisana \& Simbayi, 2002:iii).

Although more community-based research at the level of government is underway, the sparsity of qualitative research, as elucidated above, is, for the moment, remissness. Accordingly, the need to add to the sparsity of qualitative investigation of meaning-making of a group of South Africans in their experience of living with HIV/ AIDS motivates this study.

\section{RESEARCH METHOD}

\section{Research design}

Primarily, the aim of this study is to describe, simply and clearly, the experiences of what it means to live with HIV in South Africa. More specifically, the lived experiences of four middle-class South Africans diagnosed with HIV are described. Enabling for the richness and profundity of the human experience necessitated the adoption of qualitative and phenomenological research methodology.

Phenomenology refers to a philosophical movement that has received its most persuasive impetus, formulation and defence from German philosopher Edmund Husserl. Husserl's phenomenology takes, as its modus operandi, Cartesian attention to the primacy of first-person experience and the Kantian search for basic 'a priori' principles (Solomon, 1980:1).

From a phenomenological perspective, it is assumed 
that the creation of meaning emerges both for the individual and for others through their experience of the world. Thus, the major focus of attention of this research was on the world of everyday experience as expressed in everyday language and pure phenomena, autonomous of and prior to reflective interpretation (Valle, King \& Halling, 1989:9-10). Given directly and immediately in human experience, the Liebenswelt (life-world), becomes a point of departure of the phenomenological psychologist. The life-world is the beginning, the foundation upon which phenomenological thought is built. Rather than a construction of consciousness, the lifeworld is co-created in the dialogue of person and world (in Valle et al. 1989:9).

Liebenswelt is prior to and the foundation of reflective thought, which phenomenological psychologists describe as being pre-reflective in nature. Thus, although independent of knowledge derived from reflective thought processes, Liebenswelt, being pre-reflective (beforereflective), is indispensable as a point of departure for all knowledge. In this way, scientific knowledge could not exist without the pre-reflective life-world. That is, through description the pre-reflective life-world is brought to the level of reflective awareness where it manifests itself as psychological meaning. This is done for the purpose of understanding a phenomenon (Valle et al. 1989:9-10).

Based on the assumption that all knowledge is ultimately rooted in human experience (Segal, 1999:31), the phenomenological method describes essential structures of experience, provides a unified theory of science and knowledge and prepares the ground for descriptive exploration (Farber, 1966:529). Correspondingly, investigations that follow a descriptive methodology, such as that forwarded by phenomenological psychology, encapsulate the meaning-making of the individual in a way that this study intends. Within this context the motivation, rationale and aims of this study are elucidated.

\section{Selection of participants}

Following Polkinghorne (1989:45), participants were selected accorded to the following criteria:

- They had to have received an HIV diagnosis.

- They were aged between 30-39 years - an age thought not to be traditionally associated with the threat of death.

- They were middle class citizens. Middle class was operationalised using education level (all participants had finished 12 years of schooling), monthly income (significantly higher than minimum wage) and employment as indicators.

- They were English-speaking, verbally fluent and able to communicate their experiences.

Purposive sampling was utilised in an attempt to recruit participants that met the criteria for this research (Neuman, 1997:206). This was achieved by contacting general practitioners and HIV/AIDS medical specialists. The researcher discussed the nature of the research with the medical practitioners who agreed to ask selected patients if they would be willing to partake in this research.

It was explained that the participants would be required to engage with the researcher in a one-to-one and a half-hour interview. All participants received the same open-ended questions that called for a detailed description of what it means to live with HIV in South Africa as this pertains to their emotional, social, familial, biological and spiritual perceptual experiences. Pseudonyms of the participants choosing maintained confidentiality. Four participants were identified through this process (three males and one female). Consent of each participant was obtained that their experiences could be included in the final report and articles.

\section{Participant demographics}

Although race did not form part of the selection criteria, it happened that the four participants who agreed to commit to the study were white. In terms of the pseudonyms chosen, the participants are referred to as Anne, Mark, Robert, and Tommy.

\section{Anne}

Anne is a 38-year-old heterosexual female who has been HIV positive for nine years. In the absence of taking any antiretroviral medication, Anne follows a healthy diet and takes a daily multivitamin cocktail. Anne was infected by an ex-boyfriend whom she believes did so purposefully. Currently, Anne enjoys five years of marriage to her HIV negative husband and a career in counselling and psycho-education for an AIDS Care Centre. 


\section{Mark}

Mark is a single 39-year-old homosexual male who has been living with HIV for 18 years. According to Mark, his infector was unaware of his HIV status at the time of their relationship. Mark is currently taking antiretroviral medication. Career-wise, Mark works for a consultancy firm that provides managed health care to the business sector.

\section{Robert}

Robert is a 37-year-old homosexual male who has been diagnosed with HIV for the past 12 years. Robert is taking anti-retroviral medication and has found it to be helpful with no significant side-effects. Unless he meets someone of the same HIV status with whom he feels able to enter a relationship with, Robert plans to remains single. In terms of his infector, Robert suspects that it was his partner at the time and who subsequently died of AIDS. In his work at an HIV/AIDS coffee shop, Robert feels part of a supportive environment.

\section{Tommy}

Tommy was a 39-year-old heterosexual male who had been HIV positive for 18 months. Tommy followed a healthy eating plan and was taking a multivitamin formula to help boost his immune system. Whilst serving time in prison consequential to a drug problem, Tommy was gang raped and subsequently diagnosed with HIV. In his career, Tommy was actively involved in both HIV and drug counselling and was engaged to an HIV negative woman. Two weeks following the interview for this study, Tommy committed suicide.

\section{Ethical considerations}

The following ethical issues, as listed by Creswell (1994:150), were employed:

- Participants partook in the study voluntarily.

- Participants chose pseudonyms to be utilised in the texts to protect their anonymity.

- The research topic and objectives were clearly articulated and understood by each participant.

- Transcriptions, interpretations and reports were made available to the participants.

- The rights and protection of the participants were foremost in any decision-making process.

- Debriefing sessions were offered as required.
Elucidating the world of the subjects necessitated a change in the attitude and attunement of the researcher from a natural attitude toward a transcendental phenomenological perspective. This required that the researcher put in abeyance all existing preconceptions and presuppositions and attend rather to that which is present. In phenomenology, this process is called bracketing. The process of adopting the transcendental attitude through bracketing is called the reduction, and which literally reduces the world as it is considered in the natural attitude to a purely phenomenological realm (Valle et al. 1989:10-11). Accordingly, the phases of analysis were guided by an integration of the works of Colaizzi (1978:58), Giorgi (1975:89) and Van Kaam (1969:325).

Phase one involved the collection of data and becoming familiar with the protocols. The second phase involved the division of transcripts into meaningful units that appeared to communicate a self-contained meaning from a psychological perspective. Bracketing enabled the researcher to view the phenomenon more clearly in the creation of new constructs. By means of intuition, the researcher focused awareness on the participants experience until clearly understood.

Phase three involved the reduction of selections. Linguistic transformation was carried out by means of ordinary human ability to understand the meaning of statements. Phase four involved the integration of each meaning unit and its theme in terms of the topic under investigation. In putting the research problem to each unit and its accompanying first order profile, a second transformation was created and the essence of the situation attained. The fifth phase saw the natural meanings units (NMU'S) transformed into psychological language and then synthesised into descriptive statements of essential, non-redundant psychological meanings.

Phase six completed each individual description, centring on those aspects of the experience that are trans-situational or descriptive of the phenomenon in general. The NMU's were finally synthesised into a general description of the structure phenomenon and tested to ascertain whether it contained the necessary components of the topic explored. The hypothetical description was considered as a valid identification and description of the experience. Transformed meaning units were synthesised from the various protocols into 
a final general description. The validity endured until new cases of the experiences no longer corresponded to the constituents in the given formula.

\section{FINDINGS AND DISCUSSION}

The findings were put in dialogue with the relevant phenomenological dimensions of existence and the existing literature on the experience of living with HIV/AIDS. Where necessary, quotations from the initial descriptions were used to provide a space for the participants to speak for themselves. Common themes arising from the participants' descriptions of their experiences are discussed below:

\section{Living with HIV}

The participants elucidated the incongruities and complexities involved in living with HIV. All participants felt it important to find normality and balance within the 'abnormality' of their condition and situation. In the midst of contradiction and journey to self-acceptance, HIV seemed to force the need of the participants to be 'ordinary.' As Tommy aptly noted: "... we are normal, we just have a disease ... but there isn't a cure for HIV." Anne was still on the path to self-acceptance: "I just have to deal with my body and myself in a different way".

Attempting to normalise their situation, the contradictions and ambivalences in their daily experiences were embraced. As Mark aptly stated: “... no one is perfect and my greatest problem in the world is that we are split between too perfect and broken. We assume that to be perfect we have to be not broken, without understanding that we are multi-faceted" and further "I would be very happy if my illness was taken away from me but you can't cure it. So I just accept it and look at the new opportunities now I have changed my mindset".

\section{Self-concept}

The participants noted that their HIV status had somehow forced them to re-examine and reconstruct their understanding of self and consequently introduce shifts and modifications to the experience of self. Accordingly, the biological experience of being HIV positive profoundly impacted on the subjectivity of the participants transforming not only their physical world but si- multaneously affecting their experience of self. Dansky (1994:38) notes that oftentimes individuals with HIV/ AIDS infection are unable to discern between their sense of self and the virus, and not infrequently, self-label themselves as 'diseased' or the like. To explicate, Anne described herself in accordance to disease progression: "I am in the first stage". Robert chose to define his HIV status in terms of his symptomatology: "I'm under control. I have my ups and downs. I had pneumonia and the Karposi ... So l'm, what's the word, its not recession, it's um, its stable, it is under control'.

\section{Experience of others and community}

All participants felt that their experience and contact with others formed an essential element of their lives with HIV. In their defining community, Anne and Robert understood their sense of belonging in religion, whereas Mark and Tommy felt their community to include: "Anybody and everybody".

The participants felt that becoming HIV positive facilitated an exploration of community, support systems and relationships. Concurringly, Koopman, Gore-Felton, Marouf, Butler, Field and Gill (2000:665) posit social support as an important element in intercepting the stress experienced by HIV/AIDS individuals. All participants agreed that the supportive role of their community formed an integral part of their continued emotional well-being. Support for the participants meant having someone to sit with, talk to and share in. According to Anne: "Support can come in so many ways, it can come in just holding somebody's hand and rubbing it. Just being there, not always asking 101 questions". She also stated "... my husband is supportive and that's important to me ... I think I was able to be positive through the acceptance of my mom" and "... and the acceptance of my fiancée to start off'.

Tommy obtained much of his support from his girlfriend: "From this world I get my girlfriend who has been tremendously supportive. If I want to cry, I just go and cry, I have a shoulder to do that on. And she listens and she can analyse why I am unhappy". Tommy also obtained support from religion "God is my understanding. It's great support to me". For Mark, his friends were integral to his emotional well-being: "My friends collectively provide me with different things at different times. I have a great network. I need them to be there". Rob- 
ert identified his sense of community being closely bound to his sexual orientation and refers to the gay community when he states: "... They are there for emotional support, thank goodness".

\section{Emotions and HIV}

All participants felt the most profound impact of becoming HIV positive was on their personal emotional processes. Although the participants varied in their initial emotional response to their diagnosis, the pattern of emotions followed that of initial shock and disbelief, denial and depression to a more positive sense of self and world-view. Mark experienced an initial fear reaction: "I was in an ambulance, that probably freaked me out more than anything. I was positive and I was shocked" whilst Anne experienced thoughts of suicide. Anne felt suicide would: "... lessen the burden". According to Anne: "The first thing I thought of when thinking of HIV was death, pain, destruction, shame. Those were the things that came to mind'. She was also shocked "I couldn't believe this would happen to me".

For a time, Mark hoped he had been misdiagnosed: "Maybe they got it wrong". Tommy was initially shocked and then described being consumed by a range of emotions: "I felt anger, resentment, hate, all these, these strange things flashed through my head". He refered to his anger as a "ball of fire" - " and I had this little ball of fire in me". Mark, Robert and Tommy noted an intense sense of despair and sadness. According to Mark: "I was clinically depressed for two months. You know, I went onto treatment and I was shattered".

Three participants noted that part of their experience of coming to terms with their disease was related to acceptance of their HIV positive status and ultimately, acceptance of self. Receiving an HIV positive diagnosis inevitably introduced feelings related to the infector and with all participants describing a range of feelings that included some sense of conflict, anger and ambivalence. Over time, all participants noted that they were able to achieve forgiveness and acceptance and that this was important to their sense of well-being. According to Anne: "I realised the only way to sort this out is to take the horns and just deal with it. There is no other way, but to face whatever problem you have ...".
Robert felt that to continue his life more fully, he would need to accept his HIV status: "I guess it's just something that you have to accept that has happened. I am here to live, as best I can and hold no grudges. That's what I try to do. I just try and continue with life". Resigning his inner struggles with his HIV status, Tommy was able to move forward in his life more positively: "I have stopped the fighting, everything has calmed down to where I accept. I think that is a very, very big word, with a very, very big meaning as far as the disease and I accept where I am coming from". It would seem that the process of emotional devastation to emotional upliftment concurringly follows the process described by Kubler-Ross (1969:82) and Tegius (1992:163) of grief related to coming to terms with life threatening illness.

\section{Disclosure and social stigma}

In negotiating their inner turmoil, the participants experienced conflict, fear and anxiety regarding self-disclosure. The participants noted that self-disclosure elicited feelings of embarrassment, shame, and fear of judgement and in turn was often met with responses of intense sadness, pity, and at times, malicious prejudice and judgement. Robert noted that, "... there is still a stigma attached even in the gay community, which is really sad". According to Anne, "I lost a lot of friends in the beginning".

Lupton (1999:42) notes that individuals infected with HIV/AIDS are often placed along a continuum distinguishing the guilty from the innocent. The distinction is driven by the equivalence between lifestyle choices and health states. These discourses identify HIV/AIDS as the outcome of personal choice and in turn affirm the notion that infection is in some way deserved (Lupton, 1999:43). Accordingly, disclosure of an HIV positive status is often responded to with judgement and stigma. Although Mark met with much support during his selfdisclosure, some friends reacted rather stereotypically: "Suddenly now, something as isolated as a virus is going to make them redefine how you see me - why? It's the same as homosexuality, which is something else I had to disclose. But often that is all ... suddenly all they see is that pigeonhole of homosexuality, which is a great tragedy".

Of note is that the Nelson Mandela/HSRC study also formed part of the Nelson Mandela Foundation's HIV/ 
AIDS strategy for care and destigmatisation (Shisana \& Simbayi, 2002:1). Although the general public appear to be more accepting and understanding towards people with HIV/AIDS, this is not always the initial experience of the sufferer. Strategies for destigmatisation are however, a step in the right direction.

\section{Being-in-the-world}

The participants noted that HIV had introduced shifts in their ways of being-in-the-world as well as their ways of knowing. Furthermore, they commented that becoming HIV positive had forced them to re-examine and reformulate the stereotypes and prejudices by which they had previously lived their lives. Healthcare and a change in stereotyping was re-examined and positively changed in a manner that introduced new meaningful ways of thinking and feeling. As Robert noted: "I used to be critical, analysing people ..., which I don't do anymore. It's just too judgmental. I don't like to judge people, they have a story too".

The realisation by Anne that everyone is vulnerable to HIV/AIDS was brought about only by her own positive HIV status: "I used to think that AIDS was something that happened to girls who slept around with lots of guys and prostitutes, drug users, very poor black people ... I know better now".

\section{Methods of coping}

The participants noted different methods of coping with the stress of being HIV positive and which included support systems, laughter, gardening, music and pets. Spiritual connectedness was considered important and was attained either by reading the Bible, natural therapy or meditation. Janoff-Bulman and Frantz (1997:91-98) note spiritual connectedness to be fundamental in an individual's attempt to find meaning in his or her HIV positive diagnosis. Thus, for the participants, through new commitments and connections, they were able to partake in powerful forms of meaning-making in an attempt to discover value and significance in their lives. Robert felt more centred with various forms of natural therapy: "One of my friends is a Reiki master, so I do that once a week massage, I do meditation" and experienced that "It balances me".

Tommy coped using various strategies that were mean- ingful to him: "... by talking to whoever wants to listen to what I have to say. That releases a lot of stress, from me, and fear." He also read the Bible and stated "I found a church where I am comfortable". Anne felt comforted knowing that spiritually, she would never be alone: "You tend to turn to God a lot more, ... I know that I have a God who is a good God, who won't forsake me". For Mark, things previously taken for granted now impacted his life with deeper meaning: "... I have a tendency to choose good music in the morning" and "Every day of my life I go home, have a peanut butter sandwich, I have a cup of tea and play with my cats for half an hour. By the time that's over, I just suddenly feel everything is balanced now ... I water my garden and that really puts you into perspective about what this globe is about let me tell you, when you see a little plant grow, let me tell you".

\section{Limitations, losses and approaching death}

All participants noted experiencing a sense of loss and limitation by virtue of being HIV positive. On a legislative level, Anne felt discriminated against by virtue of being denied a bank loan and a life insurance plan. Although not wishing to immigrate, all participants felt restricted by being unable to leave South Africa: "I cannot get a bank loan being HIV positive. ... I wanted at one stage to immigrate but was told that being HIV positive and South African, I cannot'. An inability to have children was considered a great loss for Anne, as with a loss of friendships experienced by all participants.

Two participants felt their diagnosis impacted and restricted their long-term goals. Tommy noted that: "I was going to tour Africa and it has disrupted me a bit there because I won't be able to do that ..." and further: "I would only be able to do half the trip and then stop ...". Similarly, Mark was really looking forward to spending a year in Canada: "If HIV has impacted anything, it is my limitations, in that I can't live anywhere else now. Because with HIV you can't immigrate." and stated further "I got the opportunity to work in Canada for a year, which I was sorry I couldn't do".

The participants described a heightened and renewed awareness of time and their transitoriness of life. In turn, this propelled a need to begin organising and pre- 
paring for their death as well as catapulting the confrontation of tasks usually relegated to one's later years. The arranging of policies and wills helped fulfil a need to control the uncontrollable for each participant. Some participants felt the need to leave behind them a legacy by which to be remembered, and as Tommy best described: "I would like to leave a little mark. It sounds crazy but just to leave a mark where people will say, 'Tommy could do it, I can too".

Dunbar, Mueller, Medina, and Woolf (1998:148) note that the death sentence of HIV/AIDS creates the space and opportunity for some individuals to redefine and commit to living life more fully. Similarly, introspection, a process of life affirmation, a reconceptualisation of time, focusing on the present, and a new sense of connectedness with others have been observed as prevalent themes in many individuals diagnosed with HIV/ AIDS (Dunbar \& Mueller, 1995:12). Mark perhaps summed this up best when he said: "I am also aware of a time frame with my loved ones ... But I think it forces me to take time, and I am very much aware of the simple pleasures, you know, which fall into all the clichés. I am well aware that this is my life ... and to enjoy it right now ... I think a lot of us are so preoccupied with our achievements in five years" and later "I am much more consciously aware of getting things done now, rather than put them off forever ..."

\section{Discovering meaning}

For the participants, reviewing their life achievements and rediscovering spirituality facilitated depth, meaning, purpose and a sense of belongingness. They suggested that often this purpose was inextricably bound up with helping others, which consequently created the space for self-development and self-growth. As Mark noted: "It's about trying to be a better person." Tommy felt that loving others somehow helped him to make sense of his illness: "It's just about loving the people around you unconditionally, irrespective from what walk of life you come from or what you have done and to give them hope, that's my purpose here on earth".

In re-examining their lives, the participants noted HIV as forcing new life philosophies that introduced a greater sense of depth and gravity. Robert tried not to offend anyone whilst Anne said, "... now I look at them (street children) and I realise that there is such a problem out there and what is it that we can do". All participants felt HIV had introduced areas of growth and development related to a new kind of learning, maturity and greater receptiveness to others.

Ironically, in the face of illness, an exceptional opportunity for growth is created (Louw, 1994:23). According to Tommy: "My disease has matured me" and "I have grown to a point where I am a very good listener; I don't just jump the gun. I listen to people when they talk and I analyse what they have to say and I try to see where they are coming from, because most people today, when they talk, they are crying out for help indirectly". For Mark, being HIV positive provided a space for the teachings in his life to take on meaning: "So for me, HIV has great benefits. So that's why I can't believe that it was given to me by God as a punishment. It was given to me as luggage for me to learn my lessons on this earth".

\section{LIMITATIONS OF STUDY}

The aim of purposive sampling was to develop theoretical insights specific to a select population, namely: middle-class individuals diagnosed with HIV. In that qualitative research focuses on the depth of relationships, four participants from a homogeneous group, were thought to be sufficient (Neuman, 1994:221-222). However, although the sensitive and personal nature of this research introduced many difficulties in obtaining participants for the study, the small sample size and subjectivity of participant responses prevented the generalisation of the meaning-making experience to the larger population of individuals living with HIV in South Africa. Furthermore, and although this qualitative paradigm yielded fundamental insight into the subjective experiences of what it means to live with HIV, the strength of future research might best be circumscribed in the use of both qualitative and quantitative methods as well as an increased sample size. Accordingly, this might enable for the exploration of continual patterns or newly emergent themes that would provide a fuller picture of the experiences.

\section{CONCLUSION}

The experience of living with HIV might be understood as impacting and embracing transformations on an intrapersonal, interpersonal and global level, and of which involves multiple dimensions and multi-faceted experi- 
ences. This study has shown that the experience of living with HIV involved a forceful confrontation with the psychological and psychosocial facets of the self, life and one's being-in-the-world and which consequently seems to introduce and re-introduce renewed discovery in spirituality, religion and compassion in the search and finding of meaning.

Frankl (1984:113) posits the willingness to suffer as based on the meaning found in that suffering. In discovering purpose and meaning, the participants felt better able to embrace living more positively. The analysis suggests that in making sense of their experiences the participants were faced with the task of confronting their temporality and transitoriness. In turn, this facilitated a reprioritising of time and values in a way that celebrated life in the present and valued those with whom the individuals were able to share it.

It might here be apparent that meanings in situations do seem to influence human resilience and initiative. The crisis of receiving an HIV/AIDS diagnosis concerns not only the illness in and of itself, but also meaning sufferers attributed to it (Hafen, Karren, Frandsen \& Smith, 1996:37). Illness, according to Louw (1994:23), becomes an art when the sufferer is able to view the illness as an exceptional opportunity for personal growth and life purpose.

The Western world-view dictates an understanding of illness that is governed by notions of the human body as something mechanical that breaks down in the advent of ill health and with treatment focused on diagnosis, prognosis and medication. Despite this world-view dominating current studies on HIV, the power of meaning-making and purpose through spirituality, community, belonging, and emotional upliftment in the process of mental healing and well-being in the world when living with HIV, is here recognised.

Locating the experience of living with HIV and meaning-making within an existential phenomenological framework allowed for a richness and depth of understanding of the experiences under investigation. It is hoped that future research of this nature might be stimulated, providing a voice to the many silenced experiences of South Africans living with HIV/AIDS and in so doing, help others in similar situations find meaning and purpose in the face of living with this disease.
Additionally, larger studies, such as the Nelson Mandela/HSRC study, that include cross-cultural and gender differences in the experience and meaning-making of living with HIV/AIDS in South Africa, help inform more holistically, treatment programmes, health management, education and prevention.

In closure, the reasons for Tommy committing suicide are not known. Although Tommy did seem to find positive meaning in his HIV positive status, it might be suggested that the link between his being diagnosed with HIV and his experience of being gang raped was too much to work through on any level. Perhaps future research might too be guided by Tommy's act in terms of exploring the correlation between the cause of one being diagnosed with HIV and suicide.

\section{REFERENCE LIST}

COLAIZZI, PF 1978: Psychological research as the phenomenologist views it. (In: Valle, RS \& King, M eds. 1978: Existential phenomenological alternatives for psychology. New York: Oxford University).

CRESWELL, JW 1994: Research design: Qualitative and quantitative approaches. Thousand Oaks: Sage.

DANSKY, SF 1994: Now dare say everything: Tales of HIV-related psychotherapy. New York: Harrington Park.

DUNBAR, H \& MUELLER, C 1995: Women and HIV: The process of transcendence. Arete, 20:6-15.

DUNBAR, HT; MUELLER, CW; MEDINA, C \& WOOLF, T 1998: Psychological and spiritual growth in women living with HIV. Social Work, 43(2):145-153.

FARBER, M 1966: The aims of phenomenology: The motives, methods, and impact of Husserl's thought. New York: Harper \& Row. FRANKL, VE 1984: Man's search for meaning. Boston: Beacon. FREDRIKSSON, J \& BERRY, S 2003: South Africa HIV/AIDS Statistics.[Online].Available:http://www.HIV and AIDS statistics for SouthAfrica.htm [Accessed 23 July 2004].

GIORGI, A 1975: Convergence and divergence of qualitative and quantitative methods in psychology. (In: Giorgi, A; Fischer, CT \& Murray, EL eds. 1975: Duquesne studies in phenomenological psychology, Vol.2. Pittsburgh: Duquesne University).

GOULD, WB 1993: Viktor E. Frankl: Life with meaning. California: Brooks/Cole.

GRUNDLINGH, L 2001: A critical historical analysis of government responses to HIV/AIDS in South Africa as reported in the media, 1983-1994. Johannesburg: Paper Presented at the AIDS in Context International Conference.

HAFEN, BQ; KARREN, KJ; FRANDSEN, KJ \& SMITH, NL 1996 
Mind-body health: The effects of attitudes, emotions and relationships. Massachusetts: Allyn \& Bacon.

JANOFF-BULMAN, R \& FRANTZ, CM 1997: The impact of trauma on meaning: From meaningless world to meaningful life. (In: Power, M \& Brewin, C eds. 1997: The transformation of meaning in psychological therapies: Integrating theory and practice. Chichester: John Wiley and Sons, pp 91-106.)

KOOPMAN, C; GORE-FELTON, C; MAROUF, F; BUTLER, LD; FIELD, N \& GILL, M 2000: Relationship of perceived stress to coping attachment and social support among HIV-positive persons. AIDS Care, 12(5):663-672.

KUBLER-ROSS, E 1969: On death and dying. New York: Macmillan. LEVY, P 1997: Chemotherapeutic treatment of cancer: An ecosystemic study of hypnosis and attributions of meaning. Pretoria: University of South Africa. (Unpublished DPhil thesis). LOUW, DJ 1994: Illness as crisis and challenge: Guidelines for pastoral care. Doornfontein: Orion.

LOUW, D 1997: AIDS: The quest for meaning. (In: Crous, F; Havenga-Coetzer, AA \& Van den Heever, G eds. 1997: On the way to meaning: Essays in remembrance of Viktor Frankl. Johannesburg: Viktor Frankl Foundation of South Africa).

LUPTON, D 1999: Archetypes of infection: People with HIV/AIDS in the Australian press in the mid 1990s. Sociology of Health \& IIIness, 21(1):37-54.

LYELL, V 1995: Family support in the Acquired Immunodeficiency Syndrome. Johannesburg: Rand Afrikaans University. ( Unpublished MA Thesis).

MATURANA, HR 1975: The organisation of the living: A theory of the living organisation. International Journal of Man-Machine Studies, 7:313-332.

NEUMAN, WL 1994: Social research methods: Qualitative and quantitative approaches. Boston: Allyn \& Bacon.

NEUMAN, WL 1997: Social research methods: Qualitative and quantitative approaches. Boston: Allyn \& Bacon.

POLKINGHORNE, DE 1989: Phenomenological research methods. (In: Valle, RS \& Halling, S eds. 1989: Existential-phenomenological perspectives in psychology: Exploring the breadth of human experience. New York: Plenum).

PRESTI, HL 1990: AIDS: The spiritual challenge. (In: Johnson, JA \& Pizzi, M eds. 1990: Productive living strategies for people with AIDS. New York: Harrington Park).

RAGSDALE, D \& MORROW, JR 1990: Quality of life as a function of HIV classification. Nursing Research, 39:355-359.

SCHLEBUSCH, L\& CASSIDY, MJ 1995: Stress, social support and biopsychosocial dynamics in HIV-AIDS. South African Journal of Psychology, 25(1):27-30.

SEGAL, AM 1999: Architectural metaphor in psychotherapy: A phenomenological study. Johannesburg: Rand Afrikaans University. (Unpublished DPhil thesis).
SHEIKH, AA \& SHEIKH, KS 1989: Eastern and Western approaches to healing: Ancient wisdom and modern knowledge. New York: Wiley.

SHISANA, O \& SIMBAYI, L 2002: Nelson Mandela/HSRC Study of HIV/AIDS: South African National HIV Prevalence, Behavioural Risk and Mass Media Household Survey 2002. Cape Town: Human Sciences Research Council.

SNYMAN, HA 1999: The relationship between self-disclosure and psychological distress in asymptomatic HIV positive long-term survivors. Johannesburg: University of the Witwatersrand (Unpublished DPhil Thesis).

SOLOMON, RC 1980: Phenomenology and existentialism. Washington: University Press.

TEGIUS, A 1992: Dying with AIDS. (In: Ahmed, PI ed. 1992: Living and dying with AIDS. New York: Plenum, pp 153-178).

TEMOSHOK, L 1988: Psychoimmunology and AIDS. Advances in Biochemical Psychopharmacology, 44:187-197.

UNAIDS 2000: Report on the global HIV/AIDS epidemic: Joint United Nations Programme on HIV/AIDS. Geneva: WHO.

VALLE, RS; KING, M \& HALLING, S 1989: An introduction to existential phenomenological thought in psychology. (In: Valle, RS \& Halling, S eds. 1989: Existential-phenomenological perspectives in psychology: Exploring the breadth of human experience. New York: Plenum, pp 9-11).

VAN KAAM, A 1969: Existential foundation of psychology. New York: Image Books.

WEBB, D 1997: HIV and AIDS in Africa. Pietermaritzburg: University of Natal. 